\title{
Alguns aspectos da Política Fiscal para o desenvolvimento.
}

\author{
Paulo Roberto Cabral Nogueira
}

SUMÁRIo: I. Introdução. II. Tributação e poupança. III. Tributação e distribuição da renda. IV. Tributação anti-inflacionária. V. Conclusões.

\section{Introdução.}

Dentre os principais problemas com que se defronta o mundo, na segunda metade dêste século, ressalta, como o mais grave - talvez mesmo pelo fato de que daí resultam os demais - o grande desnível de desenvolvimento econômico existente entre vários países e regiões da terra.

A comparação da "renda per capita" da população de um determinado país ou continente com outros, é o principal indicador das diferenças de desenvolvimento. É sabido que a renda "per capita", por si só, não espelha necessàriamente, com precisão, o grau de adiantamento de um país. Desigualdades acentuadas na distribuição da renda nacional, seja do ponto de vista dos indivíduos ou de determinadas regiões, distorcem a apreciação dêste índice, se tomado como valor absoluto. Assim, por exemplo, o Kuweit ${ }^{1}$ do ponto de vista individual da renda "per capita"

* Dissertação apresentada na conclusão do Curso de Especialização, Ciência das Finanças, cadeira regida pelo Prof. Antônio Roberto Sampaio Doria.

1. O Kuweit com uma população de 520.000 habitantes e uma produção calculada em 1,5 bilhão de dólares (metade fornecida pelo petróleo) deu aos seus habitantes os seguintes índices de renda "per capita" (em dólares) : 1824 (1958); 3443 (1963); 3131 (1965); 3257 (1966). 
seria um dos países mais desenvolvidos da terra, como por outro lado, o Brasil, país de extensão continental, tido como subdesenvolvido em sua totalidade, pode ser considerado como um país desigualmente desenvolvido, em razão das diferenças regionais acentuadas.

Mesmo assim, èste índice é considerado fundamental, pois se uma renda "per capita" alta, nem sempre é atestado de apreciável desenvolvimento pela possibilidade da distorção apontada, o reverso, no entanto é sempre incontestável: uma renda "per capita" baixa é prova inquestionável de subdesenvolvimento. Como muito bem aponta Márıo Henrique Simonsen "afinal a fonte de recursos para o consumo e para a poupança de um país é a sua produção, cujo valor médio por habitante equivale à renda "per capita" 2 . De fato, a renda "per capita" baixa, nada mais espelha do que a fraca produção de um país.

Do interessante livro de KaHn e Wiener, $O$ ano 2000, extraímos a seguinte renda "per capita", no ano de 1965, distribuída entre os continentes, países desenvolvidos e subdesenvolvidos e alguns países mais significativos.

$$
\begin{aligned}
& \text { PNB - "per capita" - Continentes } \\
& \text { (dólares dos E.U.A. de 1965) } \\
& \begin{array}{lllllllllll}
\text { África } & \ldots & \ldots & \ldots & \ldots & \ldots & \ldots & \ldots & \ldots & 141
\end{array}
\end{aligned}
$$

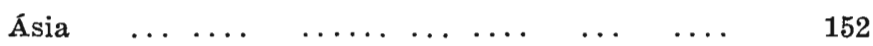

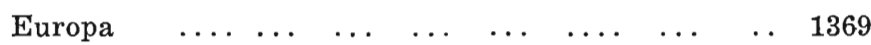

$$
\begin{aligned}
& \begin{array}{llllllllll}
\text { Oceania } & \ldots & \ldots & \ldots & \ldots & \ldots & \ldots & \ldots & \ldots & 2000
\end{array}
\end{aligned}
$$

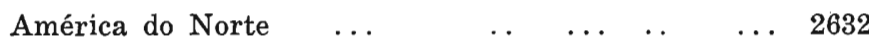

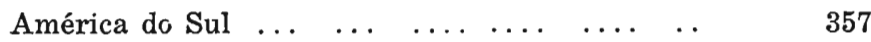

$$
\begin{aligned}
& \begin{array}{llllllll}
\text { Mundo } & \ldots & \ldots & \ldots & \ldots & \ldots & \ldots & \ldots
\end{array}
\end{aligned}
$$

No entanto o índice de analfabetismo ultrapassa a $60 \%$ da população. Outros dados curiosos do pequeno país são: o Estado emprega $50 \%$ da população; é um paraíso fiscal, pois salvo os aduaneiros, naquele país não há tributos.

cfr. The yearbook 1969, Ed. R. Digest, New York, N.Y

2. cfr. Mário Henrique Simonsen, Brasil 2001, Edição Apec, 1969, Rio, pág. 1.5 . 
Mundo dicotômico.

$\begin{array}{llllll}\text { Mundo Subdesenvolvido } & \ldots & \ldots & \ldots & \ldots & \\ \end{array}$

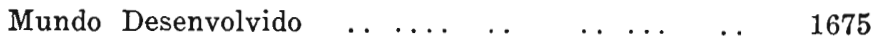

$\begin{array}{llllllll}\text { Total Mundial } & \ldots & \ldots & \ldots & \ldots & \ldots & \ldots & \ldots\end{array}$

Países principais

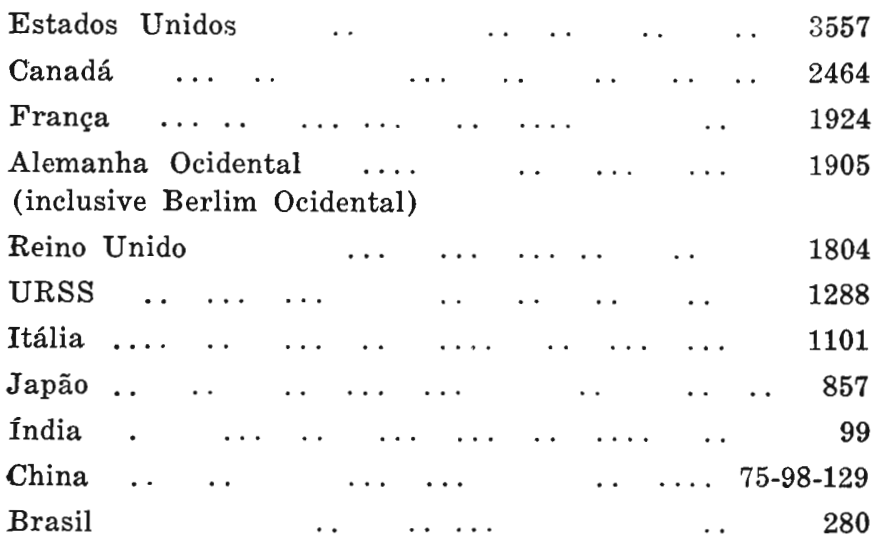

Como se vê, em têrmos gerais, a relação entre a renda "per capita" do mundo desenvolvido e do subdesenvolvido é de 1:12,4. Dentro da projeção de tais autores, no ano 2000 tal relação terá aumentada para $1: 17,7^{3}$.

A par dêste dado, outros se podem juntar, isolados ou em combinações, para dar a exata medida do desenvolvimento de um determinado país ou continente em relação aos demais.

Assim, o nivel de vida e bem estar social de um povo, pode ser aferido também pela apuração de dados como, por exemplo, o índice de mortalidade infantil ou a expectativa média de vida, o número de leitos hospitalares por

3. Herman Kahn e ANtony J. Wiener, $O$ ano 2000, Ed. Universidade de São Paulo, Edições Melhoramentos, São Paulo, 1968, págs. $189,198,210$. 
habitantes; o grau de alfabetização e duração do período da escolaridade, o número de estudantes universitários em relação à população jovem do país; o deficit habitacional, a rêde de esgotos e a percentagem de moradia com água encanada e tratada.

Enfim, sob vários aspectos, para citar apenas alguns saúde, educação e saneamento básico — se podem colhêr dados que representam o grau de desenvolvimento pelos padrões de vida dêste século, aceitos como indispensáveis ou fundamentais.

Ainda do ponto de vista econômico, além da média de renda "per capita", pode-se descer a outros índices particulares, que também dão a medida de desenvolvimento como por exemplo a percentagem da produção agrícola contra a produção industrial; a produção de aço, petróleo, veículos, etc.

Finalmente, as próprias finanças públicas têm seus postulados, que podem caracterizar os países ou continentes em áreas atrasadas ou não. Certas constatações podem generalizar-se para distinguir, as duas categorias de países pobres e países ricos. Assim, são sintomas, quase sem exceção, presentes em países subdesenvolvidos:

1. predominância marcante da tributação indireta, gravando a generalidade dos produtos, sôbre a tributação direta progressiva e fortemente personalizada;

2. receita calcada não só nestes tributos indiretos mas também fortemente dependente do comércio exterior, através de tarifas alfandegárias, tanto na importação, como na exportação;

3. pressão tributária fraca em relação ao produto interno bruto, gerando com freqüência deficits orçamentários crônicos.

Pode-se ainda aí incluir a baixa rentabilidade do sistema fiscal, em razão de má institucionalização ou fruto de ineficiência e desaparelhamento da máquina arrecadadora. 
O elenco de índices apontados, embora bem incompleto, que permitem diferenciar os vários países ou continentes em desenvolvidos ou subdesenvolvidos, dá bem uma idéia de que não é difícil o diagnóstico. O problema que assume proporções gigantescas, e preocupa a todos, é como diminuir êste abismo que segundo se prevê, tende a aumentar.

As soluções que se apontam mesmo parciais, variam tantas sejam as filosofias políticas e econômicas existentes, ou métodos possivelmente exeqüíveis.

No entanto, dentro de determinados limites, examinando-se o problema no quadro restrito de um setor, certas medidas têm aceitação da maioria dos estudiosos.

Para romper o famoso círculo vicioso da pobreza, exposto por Gunnar Myrdal, existem premissas que não podem ser abandonadas. Deixando de lado o polêmico aspecto do aumento demográfico, fixemo-nos em problemas relacionados à economia e nos quais as finanças públicas têm papel relevante a desempenhar.

O aumento da poupança ou da taxa de investimento, a mais justa distribuição da renda e o combate à inflação, principalmente à hiper-inflação crônica, são sem dúvida, três metas a serem perseguidas, por quase todos os países ou regiões que queiram sair das garras do subdesenvolvimento.

Uma débil poupança, grandes desigualdades de riqueza e inflação incontrolada, são três características presentes na maioria das nações pouco desenvolvidas.

Para êstes três males a economia financeira têm um importante papel a desempenhar. Existe um grande elenco de medidas neste campo capazes de melhorar a situação. Sem pretensão de elaborar uma completa política fiscal para acelerar o desenvolvimento econômico, vejamos a política fiscal que deve ser adotada para conseguir-se algum êxito nestes três aspectos. 


\section{Tributação e Poupança.}

A escassez de capital que caracteriza os países subdesenvolvidos é o seu maior problema e a formação dêste é o caminho principal para o desenvolvimento econômico.

A história econômica recente de países que assombraram o mundo, pelo rápido desenvolvimento, mostra que tal fato se deu pela extraordinária capacidade destas nações de formarem capital para manter uma constante e elevada taxa de investimento.

O exemplo mais frisante do após guerra nos é dado pelo Japão. Como salienta Servan Schreiber “o Japão é a potência industrial que se desenvolve, há vinte anos, no ritmo mais rápido, superior, de longe, ao ritmo norte-americano" 4

E o mesmo autor que indica ter êste país conseguido, no período de 1956 a 1963, uma formação bruta de capital, de $34 \%$ do produto nacional. Da mesma maneira impressionante é a poupança individual que atinge de 20 a $22 \%$ das rendas pessoais. Se tais taxas estão muito acima de qualquer média, o que mais chama a atenção é a persistência dêste esfôrço, que por incrível que pareça, tem conseguido resultados ainda mais espetaculares. De fato, de acôrdo com Mánio Henrique Simonsen, "entre 1961 a 1967 a sua taxa média de investimentos se manteve em $36,5 \%$ do produto interno bruto ${ }^{5}$.

Nos países em vias de desenvolvimento, parece certo que, sòmente um dirigismo econômico e uma correta política fiscal podem estimular ou mesmo criar as bases para um aumento da formação de capital.

E patente a necessidade de uma política fiscal orientada para êstes objetivos. A utilização de tributos regulatórios, com esta finalidade, tem sido uma das medidas mais

4. Jean Jacques Servan-Schretber, O Desafio Americano, Ed. Expressão e Cultura, Rio, 1968, pág. 279.

5. Ob. cit., pág. $281 / 2$. 
largamente empregadas por êstes paises. Realmente tal fato se justifica pela própria fragilidade econômica. São baixas as rendas e as poupanças individuais que são a fonte da formação de capital. Quando a renda "per capita" se situa próxima do nível de subsistência, é compreensível que o consumo das coisas essenciais a absorva quase que por completo. O que sobra para a poupança, é realmente pouco.

Para a faixa da população com renda superior, portanto com capacidade de poupança, ocorrem muitas vêzes outros fatores negativos.

Primeiro há a tendência, hoje reconhecida como o "efeito demonstração" de igualar-se aos níveis de consumo dos países mais adiantados. Segundo, por falta mesmo de um sistema compensador e seguro de poupança para investimentos produtivos, esta parcela, é amiúde, empregada em especulação imobiliária, compra de divisas estrangeiras, etc.

Duas medidas de ordem fiscal são, conforme o caso, necessárias: tributação de penalização e incentivo fiscal.

De um lado deve-se coibir o exagerado consumo de artigos de luxo através de elevadas alíquotas sôbre o seu consumo e altos impostos de importação quando tais artigos sejam estrangeiros. É um instrumento eficaz largamente utilizado pela maioria dos países. Da mesma maneira pode-se lançar mão de uma tributação que penalize os investimentos socialmente improdutivos ou de pura especulação. Até mesmo, propõem alguns, impostos sôbre a renda com base de cálculo sôbre o capital, desestimulando assim o capital paralisado ou investido improdutivamente.

Do outro lado a série de medidas denominadas incentivos, estímulos, benefícios ou reduções fiscais para a renda poupada e aplicada. Entre nós o grande impulso dado no mercado de capitais só foi conseguido depois de uma série de medidas dêste gênero. São medidas básicas, de canalização das poupanças individuais para investimentos produtivos. 
Ao fortalecimento da poupança individual deve-se também aliar o estímulo à poupança por parte das pessoas jurídicas. Isto se consegue através de medidas fiscais que beneficiem o lucro reinvestido.

Quando a fome de capitais é maior, é necessário ainda atrair capitais estrangeiros, o que se consegue novamente por meio de vantagens no campo impositivo, de modo que a maior rentabilidade do investimento provoque a imigração do capital.

Finalmente há, como que o reverso da moeda. A verdade é que não só o particular promove o desenvolvimento. O Estado é muitas vêzes o maior investidor. Muito freqüentemente, em países atrasados, o maior esfôrço para acelerar o desenvolvimento compete mesmo ao poder público.

Existe uma parcela enorme de capital a ser investida em gastos gerais sociais e em certas obras chamadas de infraestrutura, para as quais o capital privado não tem interêsse ou possibilidade de concorrer.

Surge então o fato surpreendente de que quanto mais pobre é o país, maior é a necessidade de o Poder Público investir no desenvolvimento. Quanto menor a renda "per capita" no país, maior é a dificuldade e ao mesmo tempo a necessidade de o Estado aparelhar sua arrecadação para financiar os investimentos públicos.

Se bem que tal problema se relacione também com a política orçamentária, no campo da receita êle se apresenta bastante complexo.

Realmente a determinação do nível da pressão fiscal adequada ou suportável, depende da grandeza dos gastos públicos necessários para o desenvolvimento econômico.

A constatação e muitas vêzes a crítica de que os países subdesenvolvidos têm aumentado a carga fiscal a níveis intoleráveis para a sua débil economia e baixa renda da população, justifica-se muitas vêzes em razão desta necessidade. 
Do ponto de vista do desenvolvimento econômico é irrelevante considerar se o aumento da taxa de investimento é derivada de recursos aplicados pelo setor público ou pelos particulares.

Quanto mais o Govêrno diminuir seus gastos de consumo e simples transferências tanto mais sobrará para financiar os investimentos públicos produtivos. Se a carga fiscal aumenta em razão de uma política de formação de capital, não há para a economia total do país uma diminuição de taxa de investimento.

E interessante notar neste campo a prioridade de consideração que se deve dar à receita ou à despesa, conforme seja a economia subdesenvolvida ou não.

Em países desenvolvidos, geralmente a carga fiscal pode fàcilmente estabilizar-se no nível das despesas necessárias. Nos outros, muitas vêzes se condiciona o volume da despesa à possibilidade econômica da arrecadação. A despesa governamental que não tem limites em razão da necessidade de investimentos, muitas vêzes tem de limitar-se à capacidade impositiva, fonte principal dos ingressos públicos.

\section{Tributação e distribuição da renda.}

Outro capítulo no qual a tributação tem importante papel a desempenhar no desenvolvimento econômico de países atrasados, é o auxílio que pode emprestar a uma melhor distribuição da renda nacional.

Embora não haja unanimidade sôbre qual a ótima distribuição da renda, é no entanto geralmente aceito, que extremos de pobreza em um mesmo país, constituem um entrave à eficiência produtiva, um estrangulamento à expansão do consumo, além de perpetuar uma injustiça social e instabilidade política indesejáveis.

Em uma situação dessas, de extremas diferenças, o papeI da tributação com cunho redistributivo, ultrapassa os puros limites do interêsse econômico para atingir conside- 
rações de cunho social, político ou mesmo humanitário. No entanto, com maior ou menor ênfase em tal ou qual aspecto, a quase totalidade cios governos, sejam de países econômicamente prósperos ou não, tem se utilizado da tributação, como poderosa arma para sua política redistributiva.

Das quatro clássicas regras de AdAM Smith sôbre a tributação, a primeira é justamente a da capacidade contributiva por meio de impostos proporcionais à renda.

Desta concepção de justiça em matéria fiscal, de que todos devem pagar a mesma porcentagem de sua renda como impôsto, passou-se à idéia de que não basta apenas a proporcionalidade, introduzindo-se assim o conceito de progressão. O montante do impôsto aumenta mais do que o aumento da renda, de maneira que êle se torna mais do que proporcional ao aumento desta. Hoje se aceita tal critério como a mais perfeita maneira de personalização do impôsto. Sua introdução se funda na teoria econômica da utilidade marginal. A proporcionalidade do impôsto podemos chamar de critério de eqüidade horizontal e à progressividade de eqüidade vertical.

Esta distinção é bem explicitada pelo economista da Harvard University, Отто EcKstern, ao dizer:

"Na prática, o princípio da capacidade de pagar tem duas partes isoladas. Determina não só que os ricos devem pagar mais, como também que todos os ocupantes de situações semelhantes (isto é, que têm a mesma renda) devem pagar os mesmos tributos. Esta segunda idéia, a de que "os iguais devem ser tratados igualmente, é chamada a eqüidade horizontal, ao passo que a divisão adequada do ônus dos impostos entre pessoas de diferente capacidade de pagar é denominado eqüidade vertical" 6

6. Otro Eckstein, Economia Financeira, Introdução à Política Fiscal, ed. Zahar, Rio, 1966, págs. 92 e 93. 
Pois bem. Esta progressividade do impôsto, adotada principalmente no impôsto de renda sôbre as pessoas físicas é atualmente o principal instrumento para diminuir a desigualdade na distribuição da renda dentro de uma sociedade. Dela valem-se quase todos os países que modernizaram seus sistemas fiscais.

Podem e devem os países subdesenvolvidos valer-se dêste intrumento, de forma drástica, para conseguir melhor distribuição da renda nacional? A resposta envolve uma série de considerações. Primeiro é necessário um exame da viabilidade de tal tributação que se condiciona ao estágio de desenvolvimento da economia e a certo refinamento do sistema fiscal. Segundo há limites políticos e sociológicos que podem impedir a adoção de tal medida.

$O$ assunto é fértil em polêmicas. Prova é o embate travado neste campo entre estruturalistas e monetaristas. Para avaliação correta do problema, vejamos a proposta de Celso Furtado e a crítica a ela feita por Mário Henrigue SIMONSEN.

Em resumo o economista da Cepal, atualmente lecionando na Sorbonne, propõe em sua obra "Um projeto para o Brasil", a seguinte redistribuição da renda nacional.

"Se admitimos que a população nacional está formada por 90 milhões de pessoas e que a renda líquida "per capita" é de cêrca de 350 dólares, a situação geral seria a seguinte:

$\begin{array}{cccc}\begin{array}{c}\text { \% da } \\ \text { população }\end{array} & \begin{array}{c}\text { população } \\ \text { (1000 habi- } \\ \text { tantes) }\end{array} & \begin{array}{c}\text { Renda "per } \\ \text { capita" } \\ \text { (dólares) }\end{array} & \begin{array}{c}\text { Renda total } \\ (1000 \\ \text { dólares) }\end{array} \\ 50 \% & 45.000 & 130 & 5.850 \\ 40 \% & 36.000 & 350 & 12.600 \\ 9 \% & 8.100 & 880 & 7.128 \\ 100 \% & 900 & 6.500 & 5.850\end{array}$

Se observamos êsse perfil de demanda constatamos que êle se caracteriza pelas descontinuidades. O primeiro gru- 
po tem acesso de forma marginal à economia de mercado, razão pela qual deve ser deixado de lado. O segundo grupo está formado pela massa da população que tem acesso aos produtos não-duráveis de consumo mais corrente. 0 terceiro e o quarto grupos formam um mercado diversificado, em que se integram os bens de consumo duráveis e não-duráveis. Considerando êstes últimos dois grupos conjuntamente, ou seja, os dez por cento mais ricos, a renda "per capita" é de cêr'ca de 1.500 dólares. Em síntese, temos três grupos: o primeiro com uma renda média de 130 dólares, o segundo com uma de 350 e o terceiro com uma renda média de 1.500 dólares, entre os quais existe uma nítida descontinuidade.

O objetivo a alcançar, no prazo de 3 a 5 anos, poderia ser a redução de uma quarta parte da renda do grupo de 1 por cento da população que recebe quase vinte por cento da renda nacional, e a redução de $\mathbf{1 0}$ por cento da renda do grupo de 9 por cento da população que recebe algo mais de vinte por cento da renda nacional. O primeiro grupo teria a sua renda "per capita" reduzida de 6.500 dólares para 4.875, o que ainda representaria cêrca de 14 vêzes a média nacional, e o segundo veria a sua renda "per capita", baixar de 880 para 792 dólares ou seja 2,3 vêzes a média nacional. Nem todos êsses recursos seriam retirados ao consumo, recaindo uma parte sôbre a poupança. Cabe admitir que o grupo de altas rendas consome metade de sua renda, destinando a outra parte à poupança (admitamos: 30 por cento) e ao pagamento de impostos (admitamos: 20 por cento). Vamos supor que a redução de 25 por cento incida em uma quinta parte sôbre a poupança e nas outras quatro quintas partes sôbre o consumo. Quanto ao segundo grupo, admitiremos que a redução se limitaria aos gastos de consumo, em razão do baixo coeficiente de poupança (menos de 10\%) e da natureza que esta assume. Sendo assim, os recursos adicionais de poupança monta- 
riam a cêrca de 1,9 bilhões de dólares, ou seja, 6 por cento da renda nacional" ".

Mário Henrioue Simonsen, no entanto, ao comentar esta proposta, depois de criticá-la acerbamente inclusive sob o ponto de vista técnico e estatístico e de afirmar que "não parece haver qualquer correlação nítida entre grau de desconcentração da renda e taxa de desenvolvimento econômico" conclui.

"òbviamente os dados do exercício são baseados em suposições a priori e não em evidência empírica. Mas, ainda que se ressalve êsse deslize, há vários reparos a fazer. Em primeiro lugar FurTado admite que o Govêrno poupe tôda a arrecadação tributária adicional, em nada acrescendo seus gastos correntes. Se considerarmos exógenas tôdas as decisões do Govêrno quanto a impostos e despesas essa é uma hipótese possivel; tal conjectura, no entanto, carece de apoio empírico. Em segundo lugar, não é feita a análise dos prováveis prejuízos dessa política tributária sôbre o incentivo individual ao trabalho e à inovação.

"Se êsse problema não existisse, qualquer país subdesenvolvido disporia de uma fórmula infalível para elevar a niveis excepcionais a sua taxa de poupanca: as rendas individuais seriam niveladas por baixo por um impôsto de renda violentamente progressivo, cuja arrecadação iria fortalecer a poupança do Govêrno. Em terceiro lugar, o autor esquece que uma redução abrupta da renda dessas classes poderia gerar uma crise desastrosa nas indústrias de bens duráveis, as quais, segundo o seu diagnóstico, têm como mercado exclusivo os $\mathbf{1 0 \%}$ mais ricos da população.

Quanto ao mais, louvem-se as boas intenções humanitárias dos estruturalistas. É compreensível que a desigualdade de rendas atualmente observadas no Brasil (embora não suficientemente documentada do ponto de vista esta-

7. Celso Furtado, Um projeto para o Brasil, Ed. Saga, $3^{\text {a }}$ ed., Rio, 1968, págs. $38 / 39$ e 54/55. 
tístico) fira os bons sentimentos dos cientistas sociais. natural que a atenuação progressiva dessa desigualdade se coloque como objetivo básico da política econômica. Mais inquietante, porém, do que qualquer desigualdade é a própria renda média "per capita", da ordem dos 300 dólares anuais-cifra que nos aconselha a criar riqueza e não a distribuir miséria. Os estruturalistas procuraram construir uma teoria simpática, onde o distributivismo a curto prazo ajuda a intensificação do ritmo de desenvolvimento. Mas infelizmente a economia continua sendo, ao que tudo indica, a penosa ciência do custo alternativo" 8 .

Sem nos alongarmos no exame de mérito dos dois pensamentos, parece-nos, no entanto, que uma conciliação dos pontos de vista seria realmente o ponto de equilíbrio. Difìcilmente se poderia aceitar a opinião, de que para o desenvolvimento, é irrelevante o grau de concentração da renda. Basta verificarmos que em países com extremos desníveis de renda, grande parte da população não vive em uma economia monetária. De outro lado, o objetivo a atingir em "três a cinco anos" pode trazer mais malefícios do que os vislumbrados bons resultados. Parece-nos que o autor, ao propor esta drástica tributação, pretende conciliar o objetivo de melhor distribuir a renda, com o que entende ser uma solução para um problema de conjuntura, pois sua tese central é de que o desenvolvimento foi afetado de uma paralisia, que está transformando o decênio (1960/ 170) em uma prolongada crise.

Deixando de lado êste aspecto, verificamos no entanto, que para uma política distributivista, outras formas tributárias podem ainda ser eficazes.

Há o recurso à tributação do capital. Embora conforme o caso esta seja uma forma polêmica de tributação, não pode deixar de ser considerada se houver uma resolução de enfrentar o problema de redistribuição.

8. Ob. cit., págs. 94 e $97 / 8$. 
Três são as principais modalidades de tributação do capital. Um impôsto sôbre o aumento patrimonial, ou seja, sôbre o aumento da fortuna. A tributação não alcança a totalidade do capital mas apenas os seus aumentos excepcionais. É um impôsto sôbre a mais valia. São acrésciinos patrimoniais que decorrem do acaso e sem intervenção direta do seu possuidor.

A segunda modalidade, mais comum e mais aplicada, é a tributação das transmissões do capital, principalmente "causa mortis". Como bem sintetiza Maurice Duverger, "trata-se de uma espécie de impôsto periódico, atingindo o conjunto dos capitais a cada 35 anos, em média. Do ponto de vista da igualdade permite uma personalização muito acentuada. Permite também o desenvolvimento do intervencionismo: o confisco parcial das heranças, por meio do impôsto, pode ser um meio de redistribuição dos bens" "

Realmente é meio muito eficaz de redistribuição e desconcentração de rendas, além de ter a vantagem de ser uma tributação direta, fàcilmente aplicável e suportável, sem esfôrço, pelo nôvo titular do patrimônio.

Finalmente existe a possibilidade de uma tributação geral sôbre o capital. E um tipo excepcional de imposição utilizado apenas em momentos cruciais da vida de um povo, como são exemplos práticos as imposições feitas na Europa, logo após as duas últimas guerras mundiais. No entanto não deve ser confundido com certos tipos de expropriação que já se enquadram no campo de medidas drásticas e extra-financeiras, nascidas de mudanças políticas radicais. Trata-se, isto sim, de uma amputação geral de parte do patrimônio de todos os particulares, para fazer face a urgentes gastos governamentais.

Talvez, com exceção dêste último tipo de tributação sôbre o capital, os dois anteriores têm papel importante a

9. Cfr. Maurice Duverger, Finances Publiques, Ed. Presses Unl. versitaires de France, Paris, 1963, pág. 117. 
desempenhar em uma política de melhor redistribuição da renda, com a vantagem sôbre a mecânica da forte progressão do impôsto de renda pessoal, de serem mais fàcilmente aceitos.

Por último, um capítulo relevante está reservado à política fiscal no que se refere à melhor distribuição da renda entre as várias regiões de um mesmo país. As diferenças regionais de desenvolvimento dentro dum mesmo país, como é o caso do Brasil, são muitas vêzes o principal empecilho ao rápido e desejado integral desenvolvimento.

Neste particular uma política baseada em isenções e incentivos, como temos presentemente no Brasil, é fator determinante para o deslocamento de capitais.

Uma política de investimentos regionais estimulada ou mesmo sustentada pelos incentivos fiscais, ao transferir recursos das áreas econômicamente mais prósperas para as demais, traz a curto prazo, uma substancial ativação econômica dessas áreas, com rápido aumento do nível de vida dessas populações.

Se bem que nesses casos não se possa falar em redistribuição de rendas em niveis pessoais, pois do contrário, no início de tais programas há uma maior concentração econômica nas mãos dos que já possuem o capital para investir, no entanto consegue-se realmente uma melhor distribuição de recursos em níveis regionais. Os recursos disponiveis para investimento se não forem canalizados por meio dêstes incentivos e outras medidas correlatas, tenderão a concentrar-se nas áreas que já possuem as condições de produção e mercado de consumo favoráveis.

Esta política que presentemente é adotada por uma grande maioria de nações de vários níveis de desenvolvimento, corre um grande risco.

Dada a sua generalizada aplicação, existe o perigo de os Governos exagerarem o seu emprêgo, abusando de suas modalidades, diluindo assim os resultados possiveis. Além do mais, como um verdadeiro ôvo de Colombo a sua aplicação, muitas vêzes, serve de justificativa para não se to- 
marem mediaas de outras naturezas, ainda mais indispensáveis. Pois se esta política fiscal de incentivo é um instrumento hábil para fomentar o desenvolvimento de regiões atrasadas, não é no entanto a única nem a suficiente maneira de atacar o problema. Nem tudo está resolvido com a simples adoção de uma sistemática fiscal protecionista a determinadas regiões.

\section{Tributação anti-inflacionária.}

Podemos definir a inflação como o fenômeno do maior aumento dos meios de pagamento em relação à quantidade de bens disponiveis.

Para muitos a inflação é o dado fundamental da economia no decorrer dêste século. De fato, nesta larga dimensão de tempo, não poupou nações pequenas ou grandes, ricas ou pobres. Atingiu a todos. Esta sistemática inflação mundial é tida por muitos como um indício, de cunho até alarmante, de que a humanidade tem sido incapaz de produzir o necessário às suas necessidades.

Entretanto, o que é mais sentido e estudado, é o fenômeno da inflação, com características crônicas, que afeta a parte da população da terra com níveis inferiores de vida. Como se explica tal fato? Deve ser combatida, ou até estimulada dentro de certos Limites?

Duas correntes de pensamento se entrechocam com explicações diferentes, propondo soluções também diversas. De um lado a concepção estruturalista, de outro a monetarista.

Para os primeiros é básica a definição adotada pelas Nações Unidas, em um de seus relatórios, segundo a qual, “as fontes subjacentes da inflação nos países pouco desenvolvidos se encontram nos problemas básicos do desenvolvimento econômico, nas características estruturais que apresentam os sistemas de produção dêstes países ${ }^{10}$.

10. v. U. Nations World Report, 1956. 
Sustentam os estruturalistas que não são suficientes os modelos abstratos para explicar ou combater a inflação. Naturalmente ela não ocorre no vácuo, sendo necessário encará-la dentro de uma dada realidade.

Há por parte dos estruturalistas uma grande tolerância para com a inflação. Entendem-na como um fenômeno natural do crescimento. Não pode ser combatida através de simples medidas monetárias e fiscais, sob pena de provocar largo desemprêgo e mesmo a parada ou o retrocesso do desenvolvimento econômico.

Já a corrente monetarista tem opinião oposta. Para êstes a inflação não promove o desenvolvimento e é até com êle incompativel. São partidários da estabilização dos preços. Vêem-na como um fenômeno muito mais monetário do que estrutural. Deve e pode ser contida através da política monetária e fiscal e ainda da ajuda internacional. Seu modêlo são: as regras do Fundo Monetário Internacional que se resumem em quatro medidas principais:

$1 .^{\circ}$ - Restrição creditícia para conter a excessiva expansão da oferta monetária.

$2 .^{\circ}$ - Compressão dos reajustes salariais.

$3 .^{\circ}$ - Contenção dos gastos públicos de qualquer natureza e conseqüente aumento da arrecadação para eliminar-se o deficit orçamentário.

$4^{\circ}$ - Desvalorização cambial sempre que necessácia para incrementar a exportação ${ }^{11}$.

O economista brasileiro Mário Henruque Simonsen já anteriormente citado e que pode ser apontado como um dos representantes do monetarismo, assim explica as raízes da inflação crônica:

“Em têrmo gerais a raiz sócio-política das inflações crônicas nos países subdesenvolvidos se pode encontrar na incompatibilidade da política distributiva do govêrno. Os

11. Cfr. JoÃo Pinheiro Neto, A ilusão Monetarista, Ed. Forense, Rio, 1968, pág. 56. 
diferentes grupos sociais mostram-se insatisfeitos com a sua participação no produto nacional, e o govêrno, para aplacá-los, tenta dividir o produto em partes de soma superior ao todo" 12 .

Do lado oposto temos como um dos expoentes entre nóso economista também já citado, Celso Furtado. É interessante confrontar a definição acima transcrita com a explicação dada por êste último. Para Furtado o pensamento monetarista identifica-se com o pensamento dos clássicos desde Ricardo, que vêem na economia o objetivo de estudar a "repartição do produto social". Já o estruturalismo encara-a não sob uma "perspectiva distributiva", mas como um "sistema de produção" 13 .

Como se vê, o emprêgo da tributação, como medida anti-inflacionária é meio a ser utilizado com aceitação, dentro da concepção monetarista de estabilidade econômica. E verdade qua a inflação ultrapassando certos limites, até hoje ainda não precisados, é combatida também pela corrente dos estruturalistas. Estes, como já se disse, toleram-na, desde que possa ser controlada. A partir de um certo grau concordam igualmente em que ela não é mais fator coadjuvante do desenvolvimento e precisa, portanto, ser refreada.

Para combatê-la apontam os especialistas um sem número de medidas que devem geralmente ser conjugadas para surtirem efeito.

No campo apenas financeiro, além da tarefa importante da política orçamentária de eliminação do deficit, que para muitos é o ponto básico do problema, cabe também à política fiscal papel saliente no combate inflacionário.

A regra básica num regime de excessiva expansão econômica é um aumento geral da carga fiscal e correlata diminuição de gastos. O aumento da arrecadação e a conten-

12. Ob. cit., pág. 124 .

13. Cfr. Celso Furtado, Desenvolvimento e Subdesenvolvimento, Ed. Fundo de Cultura, Rio, 1961, pág. 21. 
ção dos gastos públicos, além de colaborarem para o equilíbrio orçamentário, reduzem a propensão do consumo, fazendo diminuir a alta dos preços.

0 aumento desta carga fiscal pode no entanto ser mais eficaz, se fôr representado pelo agravamento de certos tipos de tributos.

Assim um sistema fiscal de cunho anti-inflacionário deve estribar-se, em princípio, em impostos que reduzam a demanda e equilibrem o comércio exterior.

Tôda a tributação direta que reduza o poder aquisitivo dos particulares é normalmente anti-inflacionária, pois reduz suas despesas de consumo nos diferentes níveis de renda.

Já a tributação de intervencionismo no comércio exterior tem motivação mais complexa.

O superavit na balança de pagamentos é um fator inflacionário em razão do aumento dos meios de pagamento que gera. Certo que esta conseqüência pode ser anulada se houver por parte do Govêrno um entesouramento desta receita, através da formação de reservas cambiais, que possam servir para cobrir futuras necessidades.

Já o deficit na balança de pagamentos, geralmente tem conseqüências diversas, conforme o país seja desenvolvido ou subdesenvolvido. Nos primeiros êle é normalmente anti-inflacionário, porém, nos segundos, se no início realmente baixa o poder aquisitivo, acaba afinal sendo fato de profundo deficit orçamentário, pois os governos terminam por intervir com subsídios, dada a grande dependência da economia dêstes países no comércio exterior. Há necessidade de manter o setor econômico dependente das exportações (produtos agrícolas e matérias primas) e manter o fluxo de importações indispensáveis ao desenvolvimento ${ }^{14}$.

14. Cfr. José Nabantino Ramos. Inflação e Deflação, Ed. Ramos, Medeiros \& Cia., São Paulo, 1964, 2n Ed., págs. 209/213. 
Há uma constante perda de rendimentos nas relações de troca entre países subdesenvolvidos (exportadores de matérias primas) com os países desenvolvidos (exportadores de produtos industrializados) de maneira a exigir dos primeiros um aumento constante de suas exportações para, pelo menos contrabalançá-las com as importações indispensáveis.

Desta maneira a política fiscal a ser adotada por êstes países é normalmente a de favores e isenções à exportação (com raras exceções os produtos primários comportam uma tributação de exportação) e um agravamento fiscal das importações que não sejam os indispensáveis bens de produç̃o.

Tais exemplos não podem, entretanto, ser categóricos. Há uma fluidez muito grande para se determinar com exatidão quais os tipos de tributos que estimulam os comportamentos desejados.

Para citarmos apenas um exemplo, veja-se que mesmo um aumento de impôsto sôbre consumo, que por ser indireto e repercussivo é tido como inflacionário, poderá ter conseqüências não inflacionárias.

Por ser impôsto sôbre bens, êle não onera as poupanças, podendo levar os consumidores a preferir poupar, ao invés de consumir, o que acarretaria maior redução na despesa dos particulares.

\section{Conclusões.}

1. O exame do sistema fiscal de um país pode ser suficiente para caracterizá-lo como desenvolvido ou subdesenvolvido.

2. Uma política fiscal voltada para os problemas básicos do desenvolvimento é indispensável aos paises atrasados.

3. Para aumentar a poupança e a taxa de investimentos dos países subdesenvolvidos é necessário uma tributa- 
ção de penalização do consumo marginal e de investimentos socialmente improdutivos, com correspondente incentivo fiscal à poupança individual e à reinversão dos lucros das pessoas jurídicas. Conforme o caso deve-se também of erecer vantagens especiais à entrada de capitais estrangeiros.

4. Nos paises subdesenvolvidos, a baixa renda de sua população é o principal fator, que impede o Poder Público de aumentar a carga fiscal, proporcionando recursos adicionais para os necessários investimentos em gastos gerais sociais e de infraestrutura.

5. Para a melhor distribuição da renda nacional entre os indivíduos existem duas principais armas: impôsto de renda progressivo das pessoas físicas e tributação do capital especialmente da transferência de capital "causa mortis" impôsto sôbre a herança.

6. Do ponto de vista financeiro, nos países de extremos desníveis de riqueza sòmente a drástica tributação das rendas e capital da minoria da população abastada é que pode, a curto prazo, diminuir a concentração da renda. Face às tensões sociais e desajustes econômicos, que tal drasticidade acarreta, o ideal portanto, é uma política distributiva firme e constante, porém mais diluída no tempo.

7 Em muitos países subdesenvolvidos há grande desigualdade na distribuição da riqueza, em níveis regionais. Nestes casos, uma política fiscal de incentivos ao investimento privado como é o caso do Brasil, é instrumento hábil para canalizar recursos a estas regiões.

8. Se a inflação é o fenômeno econômico do século atual, no entanto, é nos países subdesenvolvidos que ela assume proporções alarmantes. $O$ seu combate depende de uma série de medidas conjugadas. No campo financeiro a regra geral é o aumento dos impostos e contenção dos gastos de qualquer natureza. 